\title{
INFLUENCE OF TECTONICS ON THE EXTENT OF QUATERNARY GLACIATION IN THE ANDES
}

C.M.Clapperton'

\section{ABSTRACT}

The extent of Quaternary glaciations varies throughout the Andes. Although the lack of radiometric dating in many places precludes precise assessment of these variations, certain spatial patterns are evident. In the N. Andes (N. of $15^{\circ} \mathrm{S}$ ) glacial landforms and sediments of only the ultimate and penultimate glaciations (O-isotope stages 2, 4, 6) have been identified. In the Central Andes $\left(15-35^{\circ} \mathrm{S}\right)$ successive glaciations since at least the mid-Quaternary have been progressively less extensive. In the Southern Andes successive glaciations since the greatest glaciation at ca. $1.2 \mathrm{Ma}$ have been progressively smaller; also, the Islas Malvinas $800-1,000 \mathrm{~km}$ to the east became glaciated for the first time during the penultimate glaciation and developed an even greater number of nivo-glacial features during the last glaciation.

The segmented nature of the oceanic and continental crust along the Pacific-South American subduction zone promotes tectonic independence of parts of the Andean chain. It is argued that variations in the extent of glaciation may be largely explained by Quaternary uplift and subsidence in different places and by precipitation-shadow effects related to elevation and air mass source.

\section{INTRODUCTION}

The extent of actual glaciers in the Andes is determined by the altitude of the Equilibrium Line (ELA) which is controlled by mean annual temperature and precipitation. The ELA presently rises from

\footnotetext{
1Departament of Geography, University of Aberdeen, AB9 2UF Scotland, UK.
} 
ca. 4,800 $\mathrm{m}$ in the humid equatorial Andes to $>5,500 \mathrm{~m}$ in the dry sub-tropical/warm temperate latitudes farther south before descending sharply to ca. $250 \mathrm{~m}$ in the cool, wet climate of Fuego-Patogonia. That the ELA was formerly much lower during the late Cenozoic is abundantly clear from the distribution of glacial landforms and deposits. A review of Andean glaciation (CLAPPERTON, 1983) indicated that during the Pliocene some parts of the Andes supported glaciers as extensive as those that formed during the late Quaternary but that other parts contain evidence of only the last or last two periods of glaciation. This paper reviews the nature of the contrasting glacial evidence and examines the role of tectonic factors in explaining the apparent differential glacial histories of different parts of the Andes. Once the nature of the tectonic influence has been established, reconstruction of palaeoclimates can be made on a more secure basis.

\section{PATTERN OF QUATERNARY TECTONICS IN THE ANDES}

Ridges of high topography in the Andes are produced by two main sets of tectonic processes associated with the collision and subduction of four oceanic plates (Caribbean, Nazca, Antarctic, Scotia) beneath South America (Fig. 1). One involves compression, thrusting and crustal shortening by which blocks are uplifted along low-angled shear planes defined at the surface by major fault zones. A second concerns the development of regional magmatism which elevates the continental crust thermally and physically by the intrusion of contiguous plutons. Throughout the Andes the intensity of these processes has varied in space and time since they, in turn, are dependent upon spreading rates at the Pacific and Atlantic ocean ridges, changing directions of plate motion, and the intersection of aseismic ridges at the subduction zone. Also, plate margins are segmented leading to differential angles and rates of subduction and differential tectonically-induced events within the Andes. There are seven major segments within which morpho-structural units measuring 200-800 km exist as independent massifs, (eg., Cordillera Blanca, Peru). The last major pulse of tectonism began in the Miocene ca.10 Ma as plates in the Placific underwent major reorganisation following the break-up of the Fallaron plate into the Cocos and Nazca plates. Since then, major tectonic events have included changing patterns of volcanism, late Miocene suturing of an island arc terrane to NW South America and Pliocene collision of the Panama volcanic arc with NW South America (KELLOG, 1984). The topographic expression of these tectonics is dominated by block thrusting, which has created the non-volcanic cordilleras of the Northern Andes. Estimated rates of uplift are generally $0.8 \mathrm{~mm} /$ year $-1.5 \mathrm{~mm} /$ year but more rapid rates have been inferred by GEIGENGACK (1984) for the central Venezuelan Andes, a palaeo-oxisol that developed close to sea level now crops out along the mountain crests more than 4,000 m higher, implying 3,000-4,000 m of uplift within the last $1 \mathrm{Ma}$, and a rate of 3-4 mm/year. The broad volcanic arc in Ecuador and S.Colombia, is believed to have evolved as subduction of the massive Carnegie Ridge (hot and buoyant) 2-3 Ma ago caused up-arching and regional 


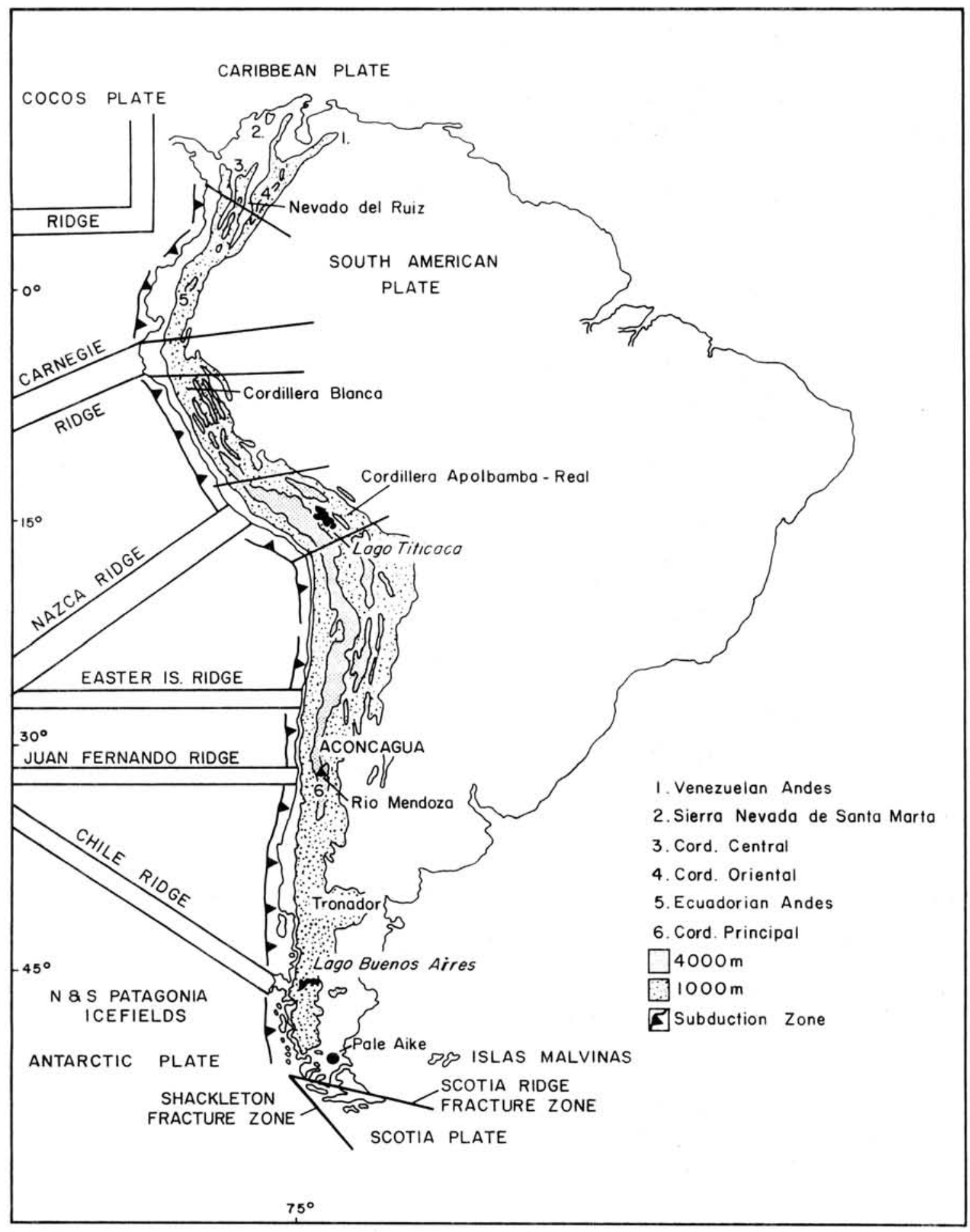

Figure 1 - Map of South America showing major tectonic elements affecting the Andes. Places mentioned in the text are named. 
fracturing of the crust (HALL \& WOOD, 1985). In the Quito area differential uplift may be $3 \mathrm{~mm} /$ year, while vertical displacement of Late-glacial moraines in the Eastern Cordillera infer a rate of $0.8 \mathrm{~mm} /$ year (CLAPPERTON, 1986). In Peru, uplifted Quaternary marine terraces and folded mid-Quaternary sediments in the Altiplano indicate active tectonics. One of the most dramatic topographic expressions of recent uplift in the Peruvian Andes is the $200 \mathrm{~km}$ long batholith of the Cordillera Blanca which contains more peaks exceeding 6,000 $\mathrm{m}$ than any other massif in the Andes. Along a major fault zone on its western margin Lateglacial moraines, outwash and alluvial fans have been displaced 5-8 $\mathrm{m}$, indicating an uplift rate during the last ca.12 ka of ca.0.4-0.7 mm/year. Marine terraces along the coast of N. and C. Chile were elevated 10-35 $\mathrm{m}$ during the last ca.125 ka. (RADTKE, 1987), implying uplift rates of $1.3 \mathrm{~mm} /$ year. Uplift has been differential along this tectonically very active coastline and it remains uncertain whether or not Andean ranges farther inland have been raised at similar rates.

A dramatic contrast existh south of lat. $40^{\circ} \mathrm{S}$ where the Chilean archipelago indicates a subsiding coastline. Explanation for this is lacking, but may involve crustal extension and thinning associated with subduction of the Chile Ridge and back-arc spreading beneath relatively thin continental crust. Basaltic volcanism in Patagonia associated with back-arc spreading has been active throughout the Pliocene and Pleistocene. Thus although subduction, magmatism and crustal compression in Patagonia have created cordilleran mountains rising above $2,000 \mathrm{~m}$, the overall tectonic expresion west of the crestline appears to have been slow subsidence during the late Cenozoic.

\section{GLACIAL SEQUENCE IN THE NORTHERN ANDES (LAT. $11^{\circ} \mathrm{N}-15^{\circ} \mathrm{S}$ )}

In the Venezuelan cordilleras of Santo Domingo, Mérida and Perija, SCHUBERT (1970, $1974,1979)$ identified two main levels of glaciation. The lowest and most extensive consists of subdued low hills composed of morainic-like material that is extremely weathered and deeply eroded; clasts nevertheless still retain glacial facets and striations. This level terminates at 2,600-2,700 $\mathrm{m}$ while farther up-valley at 3,000 3,500 m impressive moraine loops of the higher level are composed of fresh relatively unweathered till; in places they are linked with extensive terraces of fluvioglacial sediments. Although TRICART (1966) assigned deposits northeast of Mérida to the penultimate glaciation, SCHUBERT (1974) considered that oldest glacial deposits represent the maximum of the last glaciation, and that the upper, fresher moraines delimit a glacial advance of $10 \mathrm{ka}-16 \mathrm{ka} \mathrm{BP}$. These conclusions are based on limited radiocarbon dating and analogy with Colombian evidence, are very tentative and somewhat contradictory; e.g., Schubert's description of extremely weathered till implies that the lower deposit may be older than the Wisconsin glaciation.

Glaciation in Colombia has been studied in all of the cordilleras (OPPENHEIM, 1942; RAASVELDT, 1957; GONZALEZ et al., 1965; HERD, 1974; VAN DER HAMMEN, 1984; VAN DER HAMMEN et 
al., 1981, and THOURET \& VAN DER HAMMEN, 1981). There is agreement that there are three main levels of glaciation. The most extensive is at $2,700-3,250 \mathrm{~m}$; it is lowest on the eastern sides of the ranges and is lower in the Cordillera Oriental than in the Cordillera Central. As in Venezuela, it consists mainly of subdued morainic features that in places are covered with loess. RAASVELDT (1957) agreed with GANSSER (1955) that all of the glacial deposits in the Sierra Nevada de Santa Marta were formed only during the last glaciation, however, and VAN DER HAMMEN et al. (1981) assigned a mid-Wisconsin age (44-35 ka BP) to equivalent deposits in the Sierra Nevada del Cocuy, thereby implying that only the last glaciation is represented in Colombia. Such a conclusion is contrary to evidence from the Cordillera Central where the outermost of four nested moraines on Nevado del Ruiz is covered with tephra that yielded a Fission-Track (F-T) age of ca.100 ka BP (HERD \& NAESER, 1974); this implies that glaciers expanded from the massif during the penultimate glaciation to limits slightly lower than those reached during the last glaciation. However the two age determinations $(0.110 \pm 0.045 \mathrm{Ma}, 0.092 \pm 0.035 \mathrm{Ma})$ have such large standard errors that the younger extreme of a two-sigma correction would give an age equivalent to the last glaciation maximum. It is therefore prudent to remain sceptical of these data until further determinations become available. Palaeoclimatic inferences from palynological interpretations concluded that in the high plain of Bogota and adjacent mountains the successive upward and downward displacements of the vegetation zones, with open Páramo grassland periodically replacing Andean Forest (and vice versa), coincided with glacial and interglacial periods respectively during the Pliocene and Pleistocene (VAN DER HAMMEN, 1966, 1981, and HOOGHIEMSTRA, 1984). If the high plain of Bogota had reached its present altitude $(2,580 \mathrm{~m})$ by the early Quaternary, then it is probable that the adjacent Cordillera Oriental had also become elevated close to its present level; thus glaciers should have expanded and contracted in harmony with the climatic fluctuations implied by changes in the vegetation.

In Ecuador, a sequence of four glaciations separated by interglaciations equivalent to that of the European Alps was proposed by SAUER (1965). Re-examination of the evidence has shown that Sauer misinterpreted volcanic-related sediments as glacial deposits and that his main sites lie much lower than the maximum limit of glaciation (CLAPPERTON \& VERA, 1986). Radiocarbon dating of peat overlying glacial deposits in parts of the western and eastern cordilleras indicate that the biggest moraines formed before ca.38-40 ka BP when glaciers reached limits of 3,000-3,600 m (CLAPPERTON, 1987). Subsequent advances of similar extent left nested moraines some hundreds of metres within these limits and probably represent the last glaciation maximum and later stages dating to ca.14-20 ka BP. Downvalley from the large moraines and at a stratigraphically lower level, highly weathered till is present to a lower limit of a 2,750 m. The age of this deposit is not constrained radiometrically, but the degree of weathering is such that the majority of clasts $<10 \mathrm{~cm}$ size are totally decomposed into clay minerals and larger boulders are highly disaggregated; oxidation has penetrated to at least $6 \mathrm{~m}$ depth (base not seen) and veins of iron oxide commonly extend throughout the deposit. Since sediments of mid-Wisconsin age in the area have only 
been lightly weathered to ca.2-4 $\mathrm{m}$ depth, this deeply weathered till could be as old as the penultimate glaciation (CLAPPERTON, 1986).

In the Peruvian Andes, OPPENHEIM (1945) drew attention to four levels of glaciation. Near Huaras in the Cordillera Blanca, denuded moraines composed of deeply weathered material have a distinctive red colour due to intense laterisation and extend to $3,100-3,200 \mathrm{~m}$. DOLLFUS \& TRICART (1959) and TRICART (1965) also concluded from relative weathering criteria and the distribution of periglacial features that the extent of glaciation in Peru during the penultimate glaciation had been greater than during the last glaciation. CLAPPERTON (1981) also interpreted the weathered deposits near Huaras as products of the penultimate glaciation because of the contrast with much fresher sediments of the last glaciation which terminate some 400-500 m higher. He also noted extensive periglacial patterned ground and weathered blocks of granodiorite on the outer slopes of massive lateral moraines in the S.Cordillera Blanca which were also assigned to the penultimate glaciation. Only stages of the last glaciation have been radiocarbon dated; the maximum extent occurred before ca.28 ka BP (MERCER \& PALACIOS, 1977, and WRIGHT, 1983) and, as in Ecuador, appears to be equivalent to isotope stage 4.

\section{GLACIAL SEQUENCE IN THE CENTRAL ANDES (LAT. $15^{\circ}-35^{\circ} \mathrm{S}$ )}

Glacial features in this area have been studied in detail only in the Cordillera Apolobamba-Real and in the Aconcagua massif. In the north, the stratigraphy of Pliocene-Pleistocene sediments is well exposed in deep river cuts near La Paz where three major till units are interbedded with fluvioglacial sediments and two ignimbrites; these deposits extend beyond the morainic limits of the last glaciation. DOBROVOLNY (1962) assigned all of these deposits to the Pleistocene on the basis their stratigraphical relationship with fossiliferous beds in the underlying "pre-glacial" La Paz Formation. Subsequent K-Ar dating of an ignimbrite directly overlying the lowest till unit yielded an age of $3.27 \mathrm{Ma}$ however (CLAPPERTON, 1979). This demonstrates that glaciers expanded from catchments in the Cordillera Real as far during the late Pliocene as in the Pleistocene. The till formation (Milluni) stratigraphically below outwash of the last glaciation is weathered to a depth of only a few metres, whereas the next lowest till (Calvario) is intensely weathered to a depth of $40 \mathrm{~m}$ (DOBROVOLNY, 1962). The Milluni till may therefore be ground moraine of the penultimate glaciation (isotope stage 6) while the Calvario till may be from a very much earlier period. Of considerable significance is that the morainic landforms covering the piedmont west of the Cordillera Real and the Cordillera Apolobamba indicate only the last two glaciations (CLAPPERTON, 1981). LAUER \& RAFISQOOR (1986) in fact assigned all of them to only the last glaciation because they correspond to a high lake level (Lago Minchin) dated to 35-28 ka BP by SERVANT \& FONTES (1978). Thus in the absence of deep sections such as those near La Paz, it would be possible to conclude that there had 
been only two glaciations in this area, and this would be quite incorrect. Farther south the ELA rises to its maximum Andean altitude in excess of ca.5,500 m, a trend which was probably followed during glacial periods. The extent of Quaternary glaciation in this area was much less; the highest ground consists of central volcanic complexes, many of which are still active and/or were active throughout much of the Quaternary, and the glacial record is incomplete and poorly known. Some volcanic massifs rising to ca.5,500 m, show no evidence of having been glaciated despite their age of >7 Ma (JOSÉ NARANJO, 1989, pers.comm.). It thus seems that the area is so dry that only minor solifluction terraces represent the geomorphological activity of the entire late Pliocene-Pleistocene period.

The zone of Quaternary volcanism ends at lat. $27^{\circ} \mathrm{S}$, south of which a crustal segment of non-volcanic terrain has been differentially uplifted. The highest massif of this area, centred on Cerro Aconcagua $(6,960 \mathrm{~m})$, contains four Pleistocene drifts in the upper reaches of the Rio Mendoza valley on the eastern side of the range (BENGOCHEA et al., 1987). These are separable on the basis of relative position, morphology and relative weathering and indicate a former system of valley glaciers that reached ca.60 km down-valley from the base of Aconcagua. The drifts are younger than an underlying tephra dated to 250-300 ka BP by K-Ar and F-T. The most extensive drift was tentatively assigned to the penultimate glaciation, whereas the younger deposits date from stages of the last glaciation. A comparable sequence exists on the Chilean side of Aconcagua; PASKOFF (1977) listed several studies that identified glacial deposits probably of penultimate glaciation and older age. This pattern of glacier extent contrasts with that of KUHLE (1984, 1987) whose reconstruction in the Aconcagua area, based on evidence from erratics, showed that during the last glaciation glaciers terminated at $1,870 \mathrm{~m}$. It also contradicts the opinion of POLANSKI (1965) that evidence only of the last glaciation is present in the Argentinian Andes.

\section{GLACIAL SEQUENCE IN THE SOUTHERN ANDES (LAT. $35^{\circ}-56^{\circ} \mathrm{S}$ )}

North of the Patagonian icefields glaciers currently exist only on high volcanic peaks, such as Tronador, but the glacially-scoured interfluves rising to $2,000 \mathrm{~m}$ and the large lake basins surrounded by multiple morainic arcs testify to the former repeated development of mountain ice caps. FLINT \& FIDALGO $(1964,1969)$ tentatively concluded from relative weathering criteria on moraines east of the Andes that the oldest may pre-date the last glaciation, but several studies west of the mountains found clear evidence of more than one period of glaciation (BRUGGEN, 1950; WEISCHET, 1964, and PORTER, 1981). Radiocarbon dating of logs and peat identified the extent of the last glaciation around Lago Lanquihue, while mapping of drift limits and relative weathering studies have established the distribution of three older, more extensive drifts (MERCER, 1976, and PORTER, 1981). One is older than 58 ka BP, underlies a broadly rolling drift plain with subdued morainic topography and may be assigned to the 
penultimate glaciation. The other two have no obvious depositional morphology and since their clasts are totally decomposed, a considerable age is implied. East of the Andes, equivalent drifts from the same ice caps were assumed to have been eroded away or lie buried beneath the Patagonian gravels (MERCER, 1976), but recent investigations based on relative weathering studies and the K-Ar dating of lavas interbedded with tills, suggest that the outermost drift (the Picheliefu of Flint and Fidalgo) may be equivalent to the pre-penultimate glaciation drift in the Chilean Lake district (RABASSA \& ED EVENSON, 1989, pers.comm).

Farther south former ice caps terminated beyond the present shoreline west of the Andes but deposited immense morainic systems on the eastern side. These were mapped by CALDENIUS (1932) who erroneously assigned all of them to the last glaciation on the basis of teleconnections between varved glacial lake sediments in Patagonia and Scandinavia. Subsequently, MERCER (1976) and MERCER \& SUTTER (1982) discovered till sheets interbedded with basalts of Miocene and Pliocene age at higher levels than the moraine sequences, at distances of $20-50 \mathrm{~km}$ beyond the mountain front. This firmly demonstrated that large-scale glacier fluctuations have occurred in the Patagonian Andes during the last 5-7 Ma. Re-mapping in the Lago Buenos Aires area (MÖRNER \& SYLWAN, 1987) has identified five major morainic zones composed of 15 terminal ridges. Palaeomagnetic measurements have established that the outer two zones possess a reversed (Matuyama) polarity and are therefore older than $0.7 \mathrm{Ma}$; one is placed at 1.2 Ma, the other at ca.2.3 Ma. The younger three zones all have normal (Brunhes) polarity and indicate at least three major glaciations within the last 0.7 Ma. MERCER (1983) concluded that the glaciations at 7 4.6 $\mathrm{Ma}$ and 3.6 Ma were rare events whereas since $2 \mathrm{Ma}$ ice caps have repeatedly developed over the Patagonian Andes; this is supported by the marine geological record. He also conclused on the basis of $\mathrm{K}$ Ar dates from lava interbedded with till in the Pale Aike area of eastern Patagonia that the most extensive Andean glaciation had occurred at ca.1.2. Ma BP. Rough estimates of the areal extent of the southern part of the ice cap at ca.1.2 Ma and at the last glaciation maximum give values of ca. $300,000 \mathrm{~km}^{2}$ and 100,000 $\mathrm{km}^{2}$ respectively; in other words, the south Patagonian ice cap was three times more extensive during the early Quaternary than in the late Quaternary.

\section{TECTONICS AND QUATERNARY GLACIATION}

The fundamental question is, were parts of the Andes too low in the middle and early Pleistocene to support glaciers as extensive as those during the late Pleistocene? Lack of data on the pattern and rates of uplift clearly precludes realistic estimates of how much higher or lower various segments of the Andes were at the Matuyama/Brunhes boundary at ca.0.7 Ma, after which the greatest global ice volumes occurred. Since uplift rates probably varied considerably between different massifs, it 
may be impractical and misleading to apply any one value regionally. However, to illustrate a point, let us assume that uplift rates of $0.8 \mathrm{~mm} /$ year-2 $\mathrm{mm} /$ year have operated uniformly since the maximum stage of the penultimate glaciation at ca.135 ka (isotope stage 6). This means that the mountains would have been ca.100-270 $\mathrm{m}$ lower at that time, assuming no additional lowering through denudation. Because the regional ELAs during isotope stage 6 were ca.100-200 $\mathrm{m}$ lower than during the last glaciation, glaciers of the penultimate glaciation should have reached limits that were attained also by those of the last glaciation. This may well be an explanation for the apparent absence of penultimate glaciation deposits in some massifs; but the presence of weathered glacial deposits extending 400-700 lower and/or several kilometres beyond the limits of fresh deposits of the last glaciation in some areas, suggests that the estimated uplift rates may be unrealistic. Extending the same uplift rates to $0.7 \mathrm{Ma}$ indicates that all cordilleras would have been ca.560-1,400 m lower; this implies that early-middle Quaternary glaciations, which globally were generally smaller than that of isotope stage 6, would have been less extensive. Thus the deposits of earlier glaciations have probably been removed or buried during the last two glacial periods. This is clearly demonstrated at the La Paz (Bolivia) sections where the glacial morphology indicates only two glaciations, but the stratigraphy reveals evidence of two earlier ones.

In the southern part of the Central Andes it has become clear to me, (following a visit in April 1989), that the pattern of glacier expansion during the mid-late Quaternary may reflect a strong influence of tectonic uplift. The area studied in some detail by Espizua (unpublished data) is the upper part of the Rio Mendoza catchment (Cordillera Principal), which rises in the Aconcagua area (Fig. 2). Of the four Pleistocene drifts identified by Espizua, on the basis of relative weathering criteria and Uranium-series dating of interbedded travertine, the oldest and most extensive (Punta de Vacas) terminates at 2,350 m, some $60 \mathrm{~km}$ from the base of Aconcagua; this stage is assigned to isotope stage 6 (BENGOCHEA et al., 1987). The three younger drifts, all well-defined by moraines and trimlines, terminate at altitudes of $2,500 \mathrm{~m}$, $2,750 \mathrm{~m}$ and $3,250 \mathrm{~m}$, and appear to date from the last glaciation and late-glacial intervals. Believing that no older glacial deposits exist in the Rio Mendoza valley, BENGOCHEA et al. (1987) considered that high uplift rates have probably exceeded the rate of denudation, thereby causing greater relative depression of the regional ELA in the late Quaternary, leading to a greater extent of glaciation at that time compared to earlier. There are two problems associated with this interpretation. One is that a very large moraine system is present in the Rio Mendoza valley at a much lower altitude than the Punta de Vacas stage; it is near Uspallata $(1,870 \mathrm{~m})$ some $50 \mathrm{~km}$ farther down-valley from Punta de Vacas. KUHLE $(1987$, p.395) briefly mentioned this moraine, observing that since it indicates a trunk glacier ca.112 $\mathrm{km}$ long, the amount of snowline depression must have been about $1,400 \mathrm{~m}$. There is no doubt that the deposit is a moraine. The morphology is clearly preserved. At least three parallel arcs have survived fluvial dissection and curve in towards the valley centre, demonstrating that the trunk glacier most probably flowed down the Rio Mendoza valley; remnants of lateral moraines survive on the south side of the valley above the level of the of the 


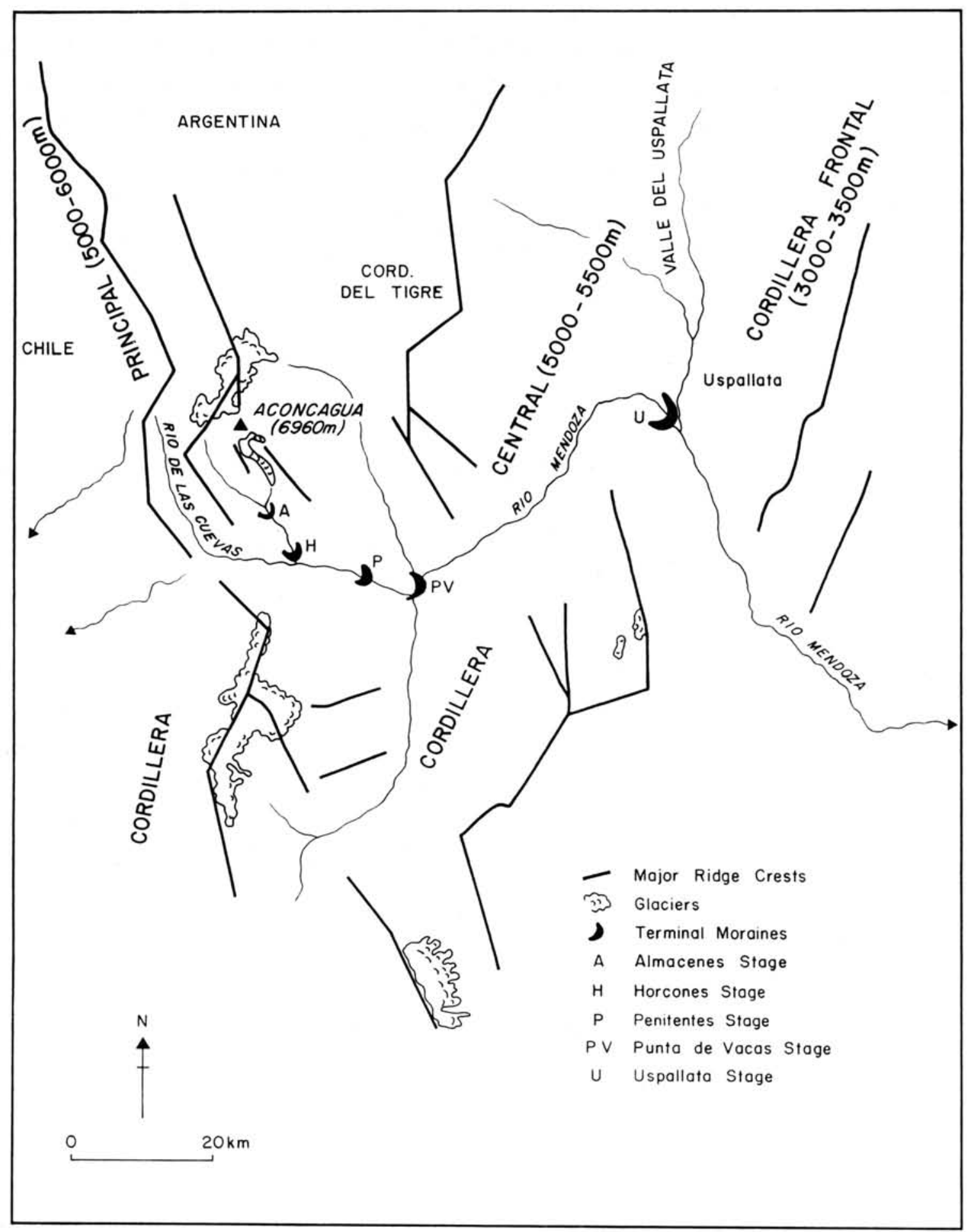

Figure 2 - Sketch of moraine stages in the Rio Mendoza valley, Argentina, based on the work of Lydia Espizua (Bengochea) and personal observations. 
younger terraces. Road cuts through the moraine and bare deflated surfaces on the crests expose a high number of glacially striated, faceted and polished clasts (c.f., KUHLE, 1987). More than 95\% of surface clasts on gently sloping outwash fans contiguous with the moraines are covered with a black patina. The degree of development of this "desert varnish" is equivalent to, if not more developed, that on the Punta de Vacas age deposits. A conspicuous white tephra ca.100 cm thick is interbedded with the outwash and related sediments. Superficially it resembles the tephra which crops out near Mendoza and which has been dated by Fission-track to $250-300$ ka BP (BENGOCHEA et al., 1987). The tephra at Uspallata has not yet been studied, but if it is part of the dated deposit, it suggests that the moraine system at Uspallata may be close in age, to isotope stage 8 that is, from the glaciation prior to that which deposited the Punta de Vacas moraine. Even although these age assignments remain uncertain, the spatial pattern of the moraine stages in the Rio Mendoza valley suggests that successive glaciations have been progressively less extensive in this part of the Andes, at least during the mid-late Quaternary. The second problem with the hypothesis proposed by BENGOCHEA et al. (1987) is that increasing elevation of the Cordillera Principal is more likely to have caused a net rise in the snowline east of the crest bacause of a greater precipitation-shadow effect (the main source of precipitation coming from the west). I have estimated the amount of ELA depression for the Horcones, Penitentes, Punta de Vacas and Uspallata stages as $840 \mathrm{~m}, 1,000 \mathrm{~m}, 1,100 \mathrm{~m}$ and 1,410 m respectively. If we assume that the Uspallata and Punta de Vacas glaciation intervals terminated at ca.250 ka BP and $130 \mathrm{ka}$ BP respectively, and that the amount of global snowline lowering was similar during the stages 8 and 6 glaciations, the apparent excess lowering (ca.300 m) of the Uspallata stage snowline could be explained by an uplift rate of ca. $2.5 \mathrm{~mm} /$ year.

In Argentine Patagonia the five major moraine zones of MÖRNER \& SYLWAN (1987) show that since the Matuyama epoch glaciers have reached successively less extensive limits also. Although the ocean-core isotopic record implies that six major glaciations of the Brunhes epoch were larger than any earlier period of global ice build-up, the stratigraphic record in eastern Patagonia shows that glaciers were more extensive in the late Pliocene-early Pleistocene than later (Fig. 3). This apparently anomalous pattern may be explained by either or both of two main factors. One is that repeated glacial erosion of the same bed throughout the late Pliocene-Pleistocene has increased the volume of the major valley systems discharging the ice streams; thus through time ice volumes of similar magnitude travel less distance to reach their equilibrium limits. A second is that in an area of tectonic subsidence, gradual lowering of the mountain divide has the effect of raising the regional ELA; thus less ice forms and outlet glaciers flow increasingly less distance down-valley.

Some support for this second hypothesis comes from the Quaternary history of the Islas Malvinas (Fig. 3). Lying some $800-1,000 \mathrm{~km}$ east of the Andean crest, these islands have a climate dominated by air masses arriving from westerly sources and receive a mean annual precipitation of only 800-1,000 mm (MOORE, 1968). The most striking anomaly of the Quaternary history of the Malvinas is that 


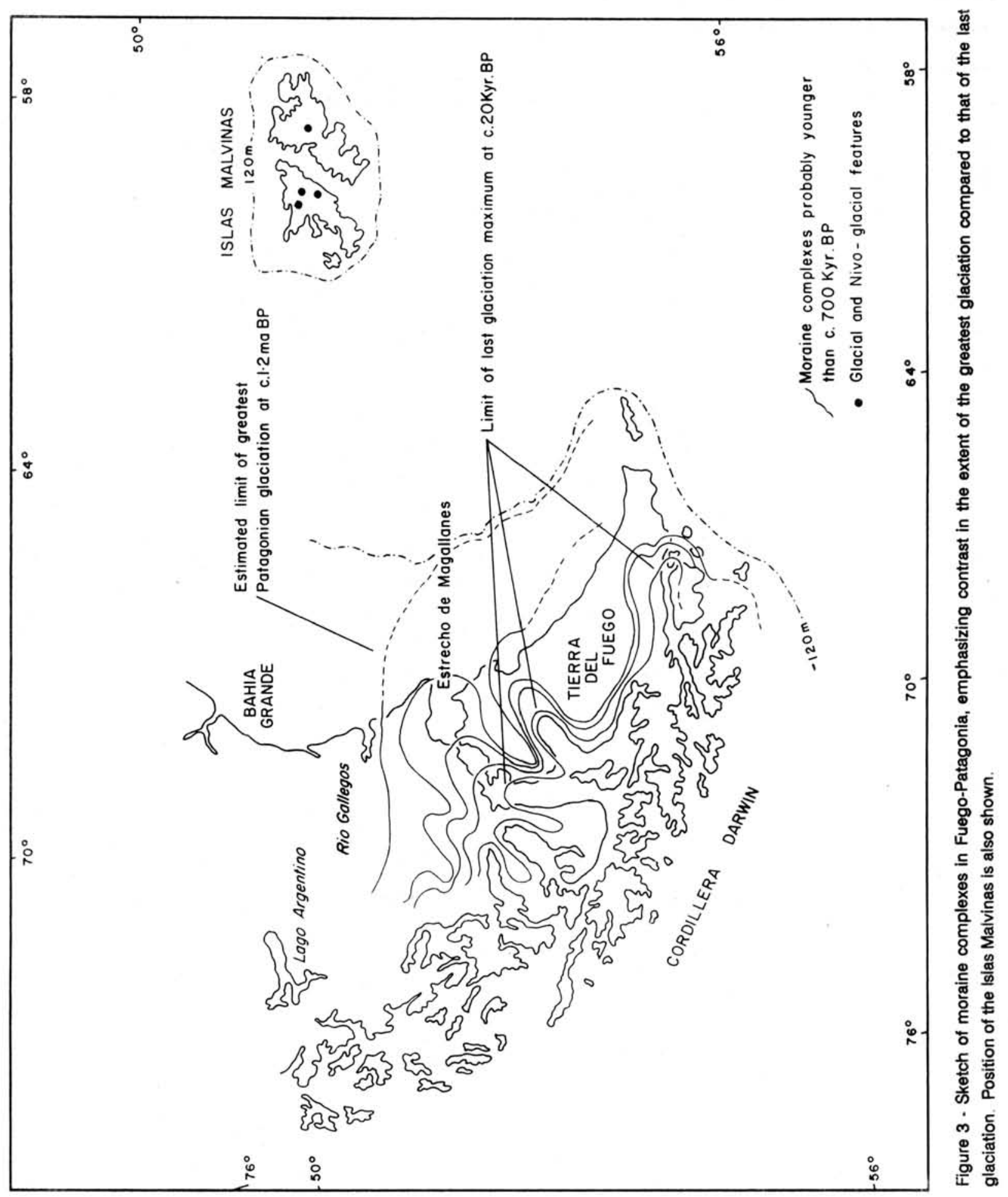


glaciers appear to have formed on only two occasions, the first of which was during isotope stage 6 . The first period of glaciation created 11 cirque basins; during the second, these were re-occupied by cirque glaciers and a further 9 cirques were formed in addition to 56 nivo-glacial features (8 nivation crests, 41 nivation hollows and 7 nivation ciques). This history and legacy of marginal glaciation is reported in CLAPPERTON (1971), CLAPPERTON \& SUGDEN (1976), ROBERTS (1984) and CLAPPERTON \& ROBERTS (1986). The puzzling question is, why did glaciers develop only during the late Quaternary? Two tectonic explanations are possible. One is that the Malvinas block has been slowly rising (along with eastern Patagonia) during the Quaternary and by isotope stage 6 had become high enough to intersect the regional snowline. This explanation is supported by the presence of raised shoreline sediments at 20-25 m and ca.60 m (CLAPPERTON \& ROBERTS, 1986), but is contradicted by the distinctive "drowned" nature of the coastline which implies subsidence in more recent times.

An alternative explanation is that the Andean crest was higher during the early-mid Quaternary, causing the W-E snowline gradient to rise more steeply on the lee side of the range bacause of a greater precipitation-shadow effect (with the dominant westerlies). Thus although temperatures may have been extremely low (as indicated by the enormous scale of periglacial features, reported in CLAPPERTON, 1975) the Malvinas uplands appers to have received insufficient snow to generate glaciers. As the Andean crest has slowly subsided during the Quaternary, a reduction in the precipitation-shadow gradient finally permitted the regional ELA to intersect the Malvinas uplands during isotope stage 6. Continued subsidence of the southernmost Andes has led to the greatest development of nivo-glacial features in the Malvinas during the last glaciation.

\section{CONCLUSIONS}

Relationships between tectonics and the extent of Quaternary glaciation in the Andes will remain relatively speculative until more detailed evidence from the mapping and dating of glacial geologic features becomes available. Nevertheless, the following conclusions may be made from the meagre data presently at hand.

1. Quaternary uplift in the northern Andes appears to have caused a much greater expansion of glaciers during isotope stages 6,4 and 2 than earlier. This presumably reflects an increased area of snow and ice accumulation above the regional snowline as the massifs continue to rise. Such an influence is particularly important in the humid equatorial zone where precipitation-shadow effects are of lesser importance. This does not imply that the northern Andes were not high enough to have been glaciated earlier in the Quaternary, but the extent of glaciation at that time may have been much less. 
2. In the different tectonic regime of the more central Andes, some massifs appear to have developed glacier systems in the late Pliocene and early Pleistocene as extensive as those of the later Quaternary. Tectonic movernents may be operating differentially, however, as in north-central Peru where the Cordillera Blanca continues to rise and where the extent of glaciation on the western (lee) side may be diminishing because of an increasing precipitation-shadow effect (air masses come from Amazonia in the east).

3. The extent of glaciation on the eastern flanks of the Andes south of lat. ca. $32^{\circ} \mathrm{S}$ appears to have progressively diminished throughout the mid-late Quatemary. In the Cordillera Principal (W of Mendoza) this is most likely to have been caused by an increased precipitation-shadow effect resulting from uplift of the massif. Whether or not there was a commensurately greater expansion of glaciers on the western side of the montains in Chile remains to be investigated. South of ca. $35^{\circ} \mathrm{S}$ the Andean crest becomes some 2,000 $\mathrm{m}$ lower, but high precipitation from the westerlies developed the largest icefield systems in all South America during the late Cenozoic glacial intervals. It is clear, however, that the extent of glaciation has progressively diminished throughout the Quaternary. Since a distinct precipitation-shadow currently exists in Patagonia east of the Andean crest, it could be argued that if the mountains are tectonically rising, as farther north, this effect could be increasing through time. However, there are two arguments against this. One is that because the mean elevation of the southern Andes is only ca.2,000 m., and since they receive such high precipitation (>4,000 mm), the lee-side "rain shadow" effects is of lesser significance than in the high drier Andes farther north. A second is that the evidence from the Islas Malvinas, together with the extensively "drowned" nature of the Chilean archipelagos, implies that tectonic subsidence is the main influence on the extent of glaciation. During each successive glaciation a smaller area will rise above the regional snowline and glacier systems will be reduced in size compared to the previous glaciation. A test of this hypothesis would be to investigate whether or not the extent of glaciation west of the divide has become equally smaller throughout the Quaternary; the pattern in the Chilean Lake District tends to support the view of overall reduction in glacier extent.

4. The more widespread implication of the tetonic influence on glacier extent is that care must be taken in assessing the significance of the glacial geologic record in evaluating the relative severity of successive glaciations during the Quaternary in South America. Differential tectonic movements will also have influenced the altitudinal pattern of vegetation zones that have been used in reconstructing Quaternary palaeoemvironments.

5. The present pattern of tectonic development in South America, with rapid uplift in the Northern Andes and subsidence in the Southern Andes, implies that the future extent of glaciation will continue to be greater in the north and smaller in the south. 
6. Perhaps the widest implication of all concerns the possible influence of tectonic uplift/subsidence of the Andean chain on the ocean-atmosphere system. Its is becoming clear that episodes of glacier buildup and decay have been synchronous between hemispheres, at least during the last $100 \mathrm{ka}$ (BROECKER \& DENTON, in press.). This supports the hypothesis that ocean-atmosphere interaction may be the dominant forcing for the scale and timing of glacial, interstadial and interglacial intervals (BROECKER et al., 1985). A major control in this relationship is the mass transfer of vapour between oceans, production of compensating flow of deep water, and the release of heat from ocean to atmosphere. In zones where zonal flux of vapour through the atmosphere is strong, as in the equatorial and temperate latitudes of South America, the position and mean elevation of mountain barriers may be critical. The northern Andes ( $N$. of lat. $10^{\circ} \mathrm{S}$ ) severely impede air masses moving west to the Pacific from the Atlantic; the southern Andes (S. of lat. $37^{\circ} \mathrm{S}$ ) influence the transfer of vapour from the Pacific to the Atlantic; the central Andes are of lesser importance because of the sub-tropical anticyclonic regime and have been arid for millions of year. It thus seems likely that variations in the height of parts of the Andes throughout the late Cezonoic may have some influence on the scale and pattern of glaciation-interglaciation worldwide. For example the conspicuous change from frequent but low amplitude intervals of glaciation before the Matuyama/Brunhes boundary ( 730 ka ago), compared to less frequent but larger scale glaciation afterwards, may be related to such tectonic influence on the ocean-atmosphere system.

\section{ACKNOWLEDGEMENTS}

I am most grateful for the financial support of Aberdeen University, The Carnegie Trust for the Universities of Scotland, the Leverhume Trust and The Royal Society for work undertaken in South America.

\section{REFERENCES}

BENGOCHEA, LE.; PORTER, S.C.; SCHWARZ, H.P. (1987) Pleistocene glaciation across the high Andes of Chile and Argentina. In: INTERNATIONAL UNION FOR QUATERNARY RESEARCH, 12., Ottawa, 1987. Abstracts. Otawa. p.127.

BROECKER, W.S.; PETEET, D.M.; RIND, D. (1985) Does the ocean-atmosphere system have more than one stable mode of operation? Nature, 315(6014):21-25. 
BRUGGEN, J.O. (1950) Fundamentos de la Geologla de Chile, Santiago.

CALDENIUS, C. (1932) Las glaciaciones cuaternarias en la Patagonia y Tierra del Fuego. Geogr. Ann., 14:1-64.

CLAPPERTON, C.M. (1971) Evidence of cirque glaciation in the Falkland Islands. Journal Glaciology, 10:121-125.

CLAPPERTON. C.M. (1975) Further observations on the stone runs of the Falkland Islands. Biuletyn Peryglacyainy, 24:211-217.

CLAPPERTON, C.M. (1979) Glaciation in Bolivia before 3.27 Ma. Nature, 227(5695):375-377.

CLAPPERTON, C.M. (1981) Quaternary glaciations in the Cordillera Blanca, Peru and the Cordillera Real, Bolivia. Revista CIAF, 6:93-111.

CLAPPERTON, C.M. (1983) The glaciation of the Andes. Quaternary Science Reviews, (2):83-155.

CLAPPERTON, C.M. (1986) Glacial geomorphology, Quaternary glacial sequence and palaeoclimatic inferences in the Ecuadorian Andes. In: INTERNATIONAL CONFERENCE ON GEOMORPHOLOGY, 1 , Manchester, 1985. Proceedings Manchester, John Wiley \& Sons. v.2, p.843-870.

CLAPPERTON, C.M. (1987) Maximal extent of late Wisconsin glaciation in the Ecuadorian Andes. Quaternary of South America and Antarctic Peninsula, 5:165-179.

CLAPPERTON, C.M. \& SUGDEN, D.E. (1976) The maximum extent of glaciation in part of West Falkland. Journal Glaciology, 17:73-77.

CLAPPERTON, C.M. \& ROBERTS, D.E. (1986) Quaternary sea level changes in the Falkland Islands. Quaternary of South America and Antarctic Peninsula, 4:99-117.

CLAPPERTON, C.M. \& VERA, R. (1986) The Quaternary glacial sequence in Ecuador: a reinterpretation of the work of W. Sauer. Journal Quaternary Science, 1:45-56.

DOBROVOLNY, E. (1962) Geologia del Valle de La Paz. Boletin Departamento Nacional de Geología, 
Ministerio de Minas y Petroleo, 3:1-153.

DOLFUS, O. \& TRICART, J. (1959) Note sur les periodes froides dans les Andes peruviennes (region de la Oroya). Comptes Rendus Sommaire des Séances de la Société Géologique de France, (8):236238.

FUNT, R.F. \& FIDALGO, F. (1964) Glacial geology of the east flank of the Argentine Andes between latitude $39^{\circ} 10^{\prime}$ S and latitude $41^{\circ} 21^{\prime}$ S. Bulletin of the Geological Society of America, 75(4):335-352.

FLINT, R.F. \& FIDALGO, F. (1969) Glacial drift in the eastern Argentine Andes between latitude $43^{\circ} 10^{\prime} S$ and $41^{\circ} 10^{\prime}$ S. Bulletin of the Geological Society of America, 80(6):1043-1052.

GANSSER, A. (1955) Ein Beitrag zur Geologie und Petrographie der Sierra Nevada de Santa Marta. Schweizerishe Mineralogische und Petrographische Mitteilungen, 35:209-279.

GIEGENGACK, R. (1984) Late Cenozoic tectonic environments of the Central Venezuelan Andes. Memoir. Geological Society of America, 162:343-364.

GONZALEZ, E.; VAN DER HAMMEN, T.; FUNT, R.F. (1965) Late Quaternary glacial and vegetation sequence in Valle de Lagunillas, Sierra Nevada del Cocuy, Colombia. Leidse Geologische Mededelingen, 32:157-182.

HAU, M. \& WOOD, C.A. (1985) Volcano-tectonic segmentation of the Northern Andes. Geology, 13:203207.

HERD, D.G. (1974) Glacial and volcanic geology of the Ruiz- Tolima volcanic complex, Cordillera Central, Colombia. Publ. Geol. Esp. Ingeomin, 8:1-48.

HERD, D.G. \& NAESER, C.W. (1974) Radiometric evidence for pre-Wisconsin glaciation in the northern Andes. Geology, 2:(12):603-604.

HOOGHIEMSTRA, H. (1984) Vegetation and climatic history of the High plain of Bogota, Colombia. Dissertations Botanicae, Cramer, Germany. 368p.

KELLOG, J.N. (1984) Cenozoic tectonic history of the Sierra de Perija, Venezuela-Colombia and adjacent 
basins. Memoir. Geological Society of America, 162:239-262.

KUHLE, M. (1984) Spuren der Hocheiszeittichen Gletscherbedeckung im der Aconcagua Gruppe (32-33 S). Zentralblatt für Geologie und Paläontologie, 1:1635-1646.

KUHLE, M. (1987) Subtropical mountain-and Highland-glaciation as Ice Age Triggers and the Waning of the glacial periods in the Pleistocene. Geo Journal, 14:393-421.

LAUER, W. \& RAFISQOOR, M.D. (1986) Die Jungpleistozane Vergletscherung im Vorland der ApolobambaKordillera (Bolivien) Erdkund, 40:125-145.

MERCER, J.H. (1976) Glacial history of southernmost South America. Quaternary Research, 6:125-166.

MERCER, J.H. \& PALACIOS, O. (1977) Radiocarbon dating of the last glaciation in Peru. Geology, 5:600604.

MERCER, J.H. \& SUTTER, J. (1981) Late Miocene-earliest Pliocene glaciation in southern Argentina. Palaeogeography, Palaeoclimatology, Palaeoecology, 38(1/2):85-206.

MOORE, D.M. (1968) The vascular flora of the Falkland Islands. Scientific Reports. British Antarctic Survey, 60:262-292.

MÖRNER, N.A. \& SYLWAN, C. (1987) Terminal moraine chronology at Lago Buenos Aires, Argentina. In: INTERNATIONAL UNION FOR QUATERNARY RESEARCH, 12., Ottawa, 1987. Abstracts. Ottawa. p.228.

OPPENHEIM, V. (1942) Pleistocene glaciations in Colombia. Revista de la Academia Colombiana de Ciências Exactas Físicas y Naturales, 9:469-482.

OPPENHEIM, V. (1945) Las glaciaciones en el Peru. Boletin Sociedad Geológica del Peru, 18:37-43.

PASKOFF, R.P. (1977) Quaternary of Chile: the state of research. Quaternary Research, 8:2-31.

POLANSKI, J. (1965) The maximum glaciation in the Argentine Cordillera. Special Paper. Geological Society of America, 84:453-472. 
PORTER, S.C. (1981) Pleistocene glaciation in the southern Lake District of Chile. Quaternary Research, 16:263-292.

RAASVELDT, H.C. (1957) Las glaciaciones de la Sierra Nevada de Santa Marta. Revista de la Academia Colombiana de Ciências Exactas, Físicas y Naturales, 9:469-482.

RADTKE, U. (1987) Marine terrace in Chile $\left(22^{\circ}-32^{\circ} \mathrm{S}\right)$ Geomorphology, chronostratigraphy and neotectonics. In: INTERNATIONAL UNION FOR QUATERNARY RESEARCH, 12. Ottawa, 1987. Abstracts. p.247

ROBERTS, D.E. (1984) Quaternary history of the Falkland Islands. PhD. Thesis, University of Aberdeen.

SCHUBERT, C. (1970) Glaciation of the Sierra Santo Domingo, Venezuelan Andes. Quaternaria, 13:225246.

SCHUBERT, C. (1974) Late Pleistocene Mérida glaciation. Boreas, 3:147-152.

SCHUBERT, C. (1979) La zona del Páramo:morfologia glacial y periglacial de los Andes de Venezuela. In: SALGADO-LABOURIAU, M.L (ed.) El medio ambiente Páramo. Caracas, IVIC. p.11-27.

SERVANT, M. \& FONTES, J. (1976) Les lacs quaternaires des hauts plateaux des Andes boliviennes. Premieres interpretations palaeoclimatiques. Cahiers ORSTOM, Serie Géologie, 10:9-23.

THOURET, J.C. \& VAN DER HAMMEN, T. (1981) Una secuencia holocénica y Tardiglacial en la Cordillera Central de Colombia. Revista CIAF, 6:609-634.

TRICART, J. (1965) Observations on the Quaternary firn line in Peru. Journal Glaciology, 5:857-863.

TRICART, J. (1966) Geomorfologla del area de Macuchies. Revista Geog., 7:31-42.

VAN DER HAMMEN, T. (1966) The Pliocene and Quaternary of the Sabana de Bogota (The Tilata and Sabana Formations). Geologie en Mijnbouw, 45:102-109.

VAN DER HAMMEN, T. (1984) Datos sobre la historia de clima, vegetación y glaciación de la Sierra Nevada de Santa Marta. In: VAN DER HAMMEN, T. \& RUIZ, P.M. (eds.) Estudios de Ecosistemas 
Tropandinos. 2.ed. Berlin, J.Cramer p.561-580.

VAN DER HAMMEN, T.; BARELDS, J.; DE JONG, H.; DE VEER, A.A. (1981) Glacial sequence and environmental history in the Sierra Nevada del Cocuy (Colombia). Palaeogeography, Palaeoclimatology, Palaeoecology, 32:247-340.

WEISCHET, W. (1964) Geomorfologla glacial de la region de Los Lagos. Comunicaciones Escuela de Geologia, 4:1-36.

WRIGHT, H.E. (1983) Glaciation around the Junin Plain, Central Peruvian Highlands. Geografiska Annale8, Ser.A., 65:35-43. 